\title{
Impacts of Climate Change as Evident in the Langtang Catchment
}

\author{
Narayan P. Gautam
}

\begin{abstract}
Nepal has felt the adverse impact of climate change even though its contribution to global greenhouse gases (GHGs) is negligible. Many scientists have expressed concern that the general rise in temperatures at high altitudes poses a serious environmental and humanitarian threat in Nepal as many glaciers and glacial lakes are located in the high Himalayas. For this study, I have observed rising temperatures in the Langtang catchment and compared the proportional rise of high altitude and low altitude temperatures as these will have serious implications for glaciers and glacial lakes in the region. As well, conducted a time series observation of water flow and noted that the river flow in the Langtang catchment are decreasing. Given these findings, Nepal may be facing increasing water scarcity while also keeping more serious watch on glacial melt.
\end{abstract}

Key words: Climate change, greenhouse gases, Langtang catchment, glacial melt, Nepal

\section{Introduction}

Climate can be defined as the average weather. Uscientifically, climate is the statistical description in terms of the mean and variability of relevant quantities over a period of time ranging from months to thousands or millions of years (IPCC 2008). The classical period for averaging these variables is 30 years as defined by the World Meteorological Organization (WMO).

Climate change refers to a change in the state of the climate that can be identified by changes in the mean and/or the variability of its properties and that persists for an extended period, typically decades or longer (IPCC 2008). Climate change may be due to anthropogenic causes or natural processes. The United Nations Framework Convention on Climate Change (UNFCC) also defines climate change in Article 1 as follows: "A change of climate which is attributed directly or indirectly to human activity that alters the composition of the global atmosphere and which is in addition to natural climate variability observed over comparable time periods" (IPCC 2008).

Global warming is considered as one of the major factors causing climate change. Even a conservative estimate of $1^{\circ} \mathrm{C}$ increase could have dramatic effects for all aspects of human life. For example, during the medieval warming period (1200-1500 AD), and during the little ice age (1600-1700AD) the average temperatures were $0.5^{\circ} \mathrm{C}$ higher and $0.5^{\circ} \mathrm{C}$ lower respectively than they are today (Khaliq et al. 1997).

Anthropogenic climate change refers to climatic change resulting from human activity. Human activity that could possibly change the climate include emission of gases into the atmosphere, industrial activities, development of extensive cities, pollution of water ways and cities, diversion of water, creation of thousands of dams and lakes, conversion of grassland or forest to cropland, agricultural activities (Piechota and Garbrecht 2006).

Scientific studies have shown that due to a higher concentration of GHGs in the atmosphere, global warming has intensified. The higher carbon dioxide concentration has resulted from the burning of fossil fuels (coal, oil and natural gas) and deforestation. The global carbon dioxide $\left(\mathrm{CO}_{2}\right)$ concentration increased from 316 parts per million (ppm) in 1959 to $389 \mathrm{ppm}$ in 2008 (Gautam 2010).

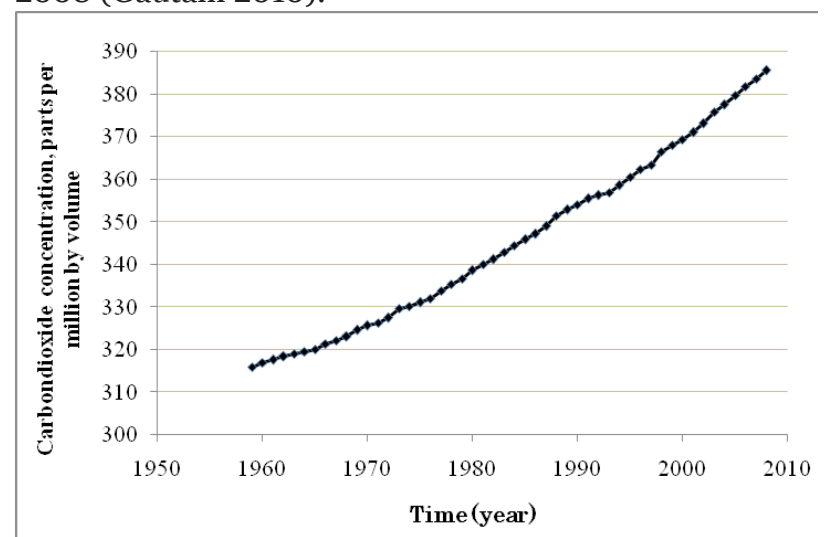

Figure 1: Carbon dioxide concentrations at Mauna Loa, Hawaii (Gautam 2010)

Climate is dynamic and changes through cycles influenced natural events such as continental drift, volcanoes, the earth's tilt, and ocean currents. These changes are being studied through historical evidence of tree-rings, pollen samples, ice-cores, and sea sediment.

\section{Physiographic and Climate Change of Nepal}

Nepal is a mountainous and landlocked country having an area of 147,181 square kilometers. The country is located between 26022' to 30027' north latitudes and 80004' to 88012' east longitudes. It occupies about 0.03 percent of the total land of the earth and about two-thirds of its land is hills and mountains. It extends approximately $885 \mathrm{~km}$ east to west and about $193 \mathrm{~km}$ north to south. Elevation of the country starts from $61 \mathrm{~m}$ to $8848 \mathrm{~m}$ within a span of less than $200 \mathrm{~km}$.

The World Wildlife Fund (2005) reports that the Nepal Himalaya contains 3,252 glaciers and 2,323 lakes above $3,500 \mathrm{~m}$ above mean sea level (amsl). Glaciers cover an area of $5,323 \mathrm{~km} 2$ with an estimated ice reserve of $481 \mathrm{~km} 3$. By basin, the Koshi River contains 779 glaciers and 1,062 lakes; Gandaki River basin consists 


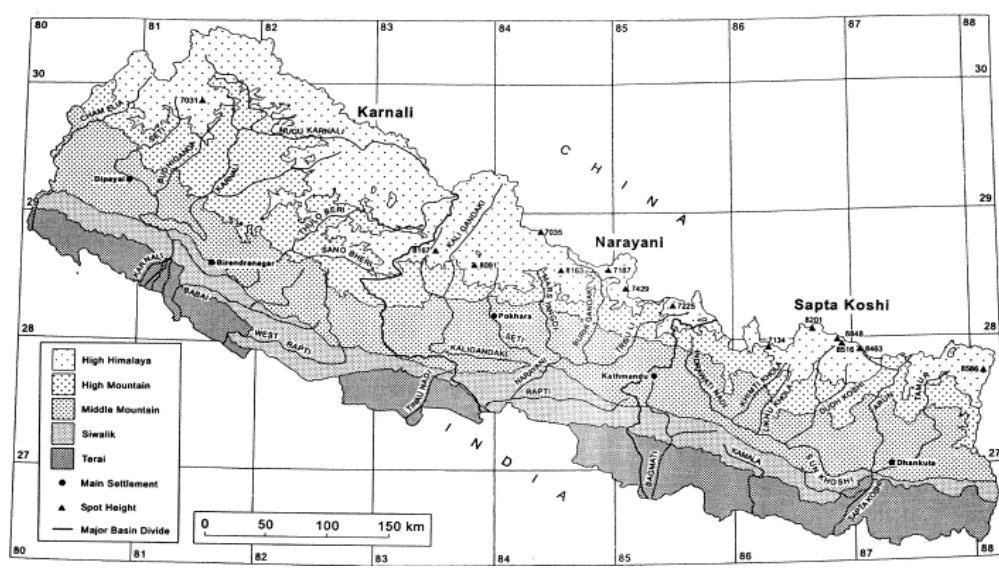

Figure 2: Physiographic condition of Nepal with its river systems (Hannah et al. 2005)

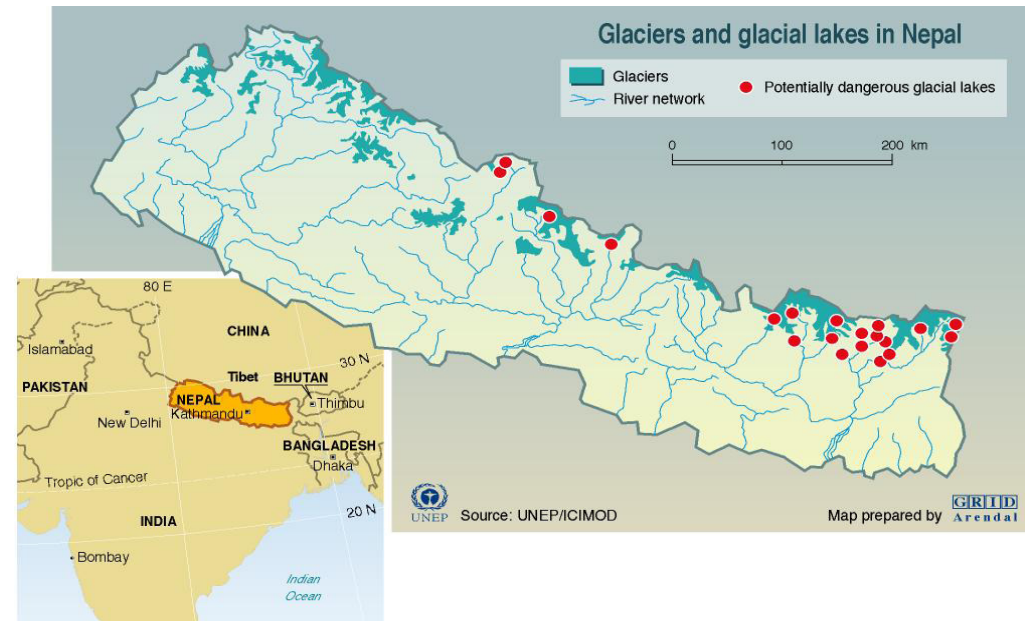

and cold desert conditions.

Impacts of Climate Change: Global, Asian and Nepalese Contexts

Impacts of climate change can be categorized both positively and negatively. In a positive sense, winters will be less cold and more vegetation can be produced in high altitudinal areas. However, the rise in mean temperatures, currently projected to be as high as $5.8^{\circ} \mathrm{C}$ (Bajracharya et al. 2007) over the next century, may produce several of the negative consequences listed in table 1 (IPCC 2008).

In global context, 2009, ranked as the fifth warmest year on record since the beginning of instrumental climate records around 1850. On the decadal scale, the 2000s (2000-2009) were warmer than the 1990 , which in turn were warmer than the 1980 and earlier decades (WMO 2009).

Water distribution is uneven in Asia and it has a large and dense population with a fast growth rate. In this setting, it is expected that climate change will intensify water scarcity in Asia, adding to already present socio-economic stresses (IPCC 2008).

The Himalayan regions are located in the northern part of Indian sub-continent. The Himalayan region contains many rivers and the abundance of water in the area influences meteorological and hydrological conditions
Figure 3: Glacier and glacial lakes in Nepal (Grid2009)

of 1,025 glaciers and 338 lakes; the Karnali River basin consists of 1,361 glaciers and 907 lakes; and, the Mahakali basin (within Nepal), consists of 87 glaciers and 16 lakes.

Glaciers are an important means of freshwater storage in Nepal as they accumulate water in monsoon and winter seasons at higher altitudes and provide melt-water at lower elevations during the dry seasons. The importance of glaciers extends beyond Nepal: the Ganges Basin draws up to $80 \%$ of its water flow from Nepali rivers (World Bank 2012).

Nepal is divided into five characteristic climatic zones in a span of less than $200 \mathrm{~km}$ (south to north), which are categorized as follows (ICIMOD 2002).

- Hot monsoon climate in the Terai, inner Terai, and Siwalik regions with a hot and wet summer, and mild and dry winter.

- Warm temperate monsoon climate in the Middle Mountains up to a height of about 2,100 meter above mean sea level (amsl).

- Cool temperate monsoon climate in the Middle Mountains and the High Mountains between 2,100 and 3,300 amsl.

- Alpine climate in the High Mountain region up to a height of about $4,800 \mathrm{amsl}$.

- Tundra type of climate above the snow line, that is, 5000m (WECS 2011) where there is perpetual frost

\begin{tabular}{|c|c|}
\hline $\begin{array}{c}\text { Observed } \\
\text { effect }\end{array}$ & Observed / possible impacts \\
\hline $\begin{array}{l}\text { Increase in } \\
\text { atmospheric } \\
\text { temperature }\end{array}$ & $\begin{array}{l}\text { - Reduction in water availability in } \\
\text { basins fed by glaciers that are } \\
\text { shrinking, as observed in some cities } \\
\text { along the Andes in South America }\end{array}$ \\
\hline $\begin{array}{l}\text { Increase in } \\
\text { surface water } \\
\text { Temperature }\end{array}$ & $\begin{array}{l}\text { - Reductions in dissolved oxygen } \\
\text { content, mixing patterns and self- } \\
\text { purification capacity } \\
\text { - Increase in algal blooms }\end{array}$ \\
\hline Sea-leve & ion of coastal aquifers \\
\hline $\begin{array}{l}\text { Shifts in } \\
\text { precipitation } \\
\text { patterns }\end{array}$ & $\begin{array}{l}\text { - Changes in water availability due to } \\
\text { changes in precipitation and other } \\
\text { related phenomena (e.g. groundwater } \\
\text { recharge, evapotranspiration) }\end{array}$ \\
\hline $\begin{array}{l}\text { Increase in } \\
\text { inter-annual } \\
\text { precipitation } \\
\text { variability }\end{array}$ & $\begin{array}{l}\text { - Increase the difficulty of flood control } \\
\text { and reservoir utilization during the } \\
\text { flooding season }\end{array}$ \\
\hline $\begin{array}{l}\text { Increased } \\
\text { evapotrans } \\
\text { piration }\end{array}$ & $\begin{array}{l}\text { - Water availability reduction } \\
\text { - Salinization of water resources } \\
\text { - } \quad \text { Lower groundwater levels }\end{array}$ \\
\hline $\begin{array}{l}\text { More frequent } \\
\text { and intense } \\
\text { extreme } \\
\text { events }\end{array}$ & $\begin{array}{l}\text { - Floods affect water quality and water } \\
\text { infrastructure integrity, and increase } \\
\text { fluvial erosion, which introduces } \\
\text { different kinds of pollutants to water } \\
\text { resources } \\
\text { - Droughts affect water availability and } \\
\text { water quality }\end{array}$ \\
\hline
\end{tabular}

Table 1: Observed effects of climate change and its observed/possible impacts on water services in global perspectives (IPCC 2008) 


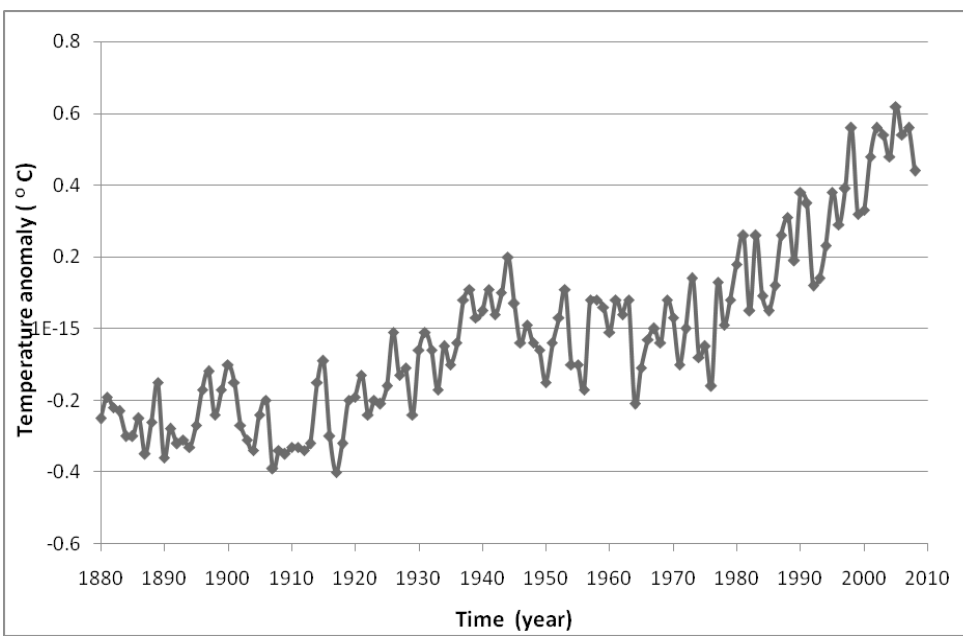

Figure 4: Trend of global average surface temperature (Gautam, 2010)

in the Indian sub-continent. It is assumed that even a minor change in the climate of the Himalayas could cause disastrous consequences on the socio-economic condition of millions of peoples living downstream of the river systems (Bhutiyani et al 2007).

Although Nepal's carbon emissions are negligible in the global context, it has been facing several adverse impacts of climate change. One climatic studies of Koshi basin of Nepal has shown that there is a high population pressure in the region (Sharma et al. 2000). The study indicated that the population of the basin grew at the rate of one percent per annum during the past four decades. It signified that the anthropogenic factors are increasing to enhance climate change in the Koshi basin, the eastern part of Nepal.

For an alternative perspective, we can divide the impacts of climate change in Nepal among various sectors: water resources, health, forestry, agriculture, biodiversity, economy, tourism and so on.

- Water. In Nepal, people consider monsoon as 'life giving rain'. More than $80 \%$ of the population depends on agriculture, which is predominantly fed by monsoon rain. Any change in the monsoon system directly affects the production of food. In recent years, concern for monsoon rains has been legitimated by increasing rainfall intensity and droughts throughout the country.

- Health. Climate change may be intensifying the spread of mosquitorelated diseases such as malaria, dengue fever, Ross River virus, and West Nile virus (Climate Institute 2013). Gautam (2005) has shown that a mosquito problem has emerged in the high Jomsom valley of Nepal (2,700m). Aryal et al. (2013) found that the average annual temperature has increased by $0.13^{\circ} \mathrm{C}$ in the upper Mustang region, a rate faster than temperature increases in the central Himalayas of Nepal and the Tibetan Plateau.

- $\quad$ Forestry. Gaire et al (2005) studied dynamics of Abiesspectabilisin relation to climate change at the tree line eco tone in Langtang National Park. They collected tree core sampling and found that upward advancement of tree line should be expected in the coming decades. They further concluded that the general increase of winter minimum temperatures might be responsible for the upward advancement of the tree line and early melting of snow.

- Biodiversity. Chaudhary and Bawa (2011) conducted field surveys in Darjeeling and West Bengal of India and in the Ilam district of Nepal to analyze local perceptions of climate change. Respondents reported changes in biodiversity

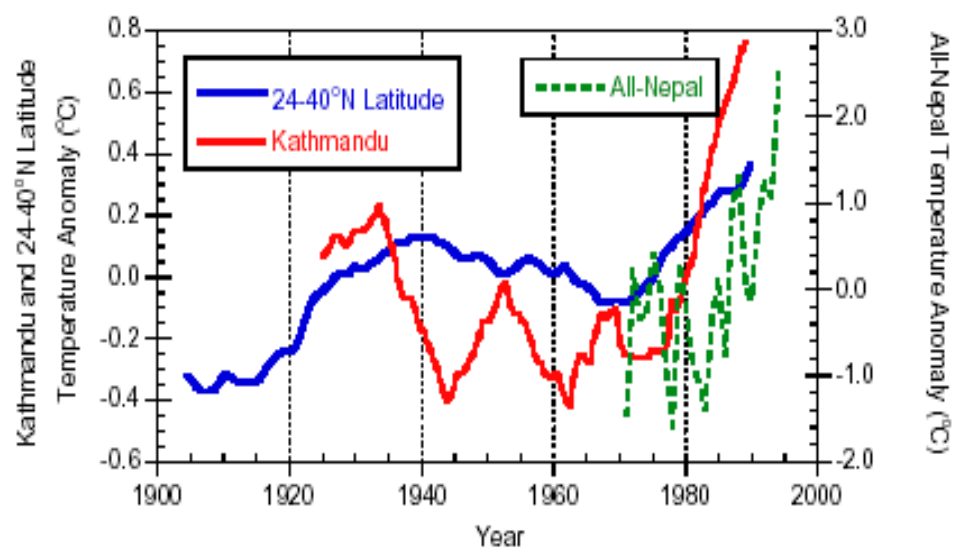

Figure 5: Comparison of temperature trends for Kathmandu with allNepal and global pattern (WWF 2005)
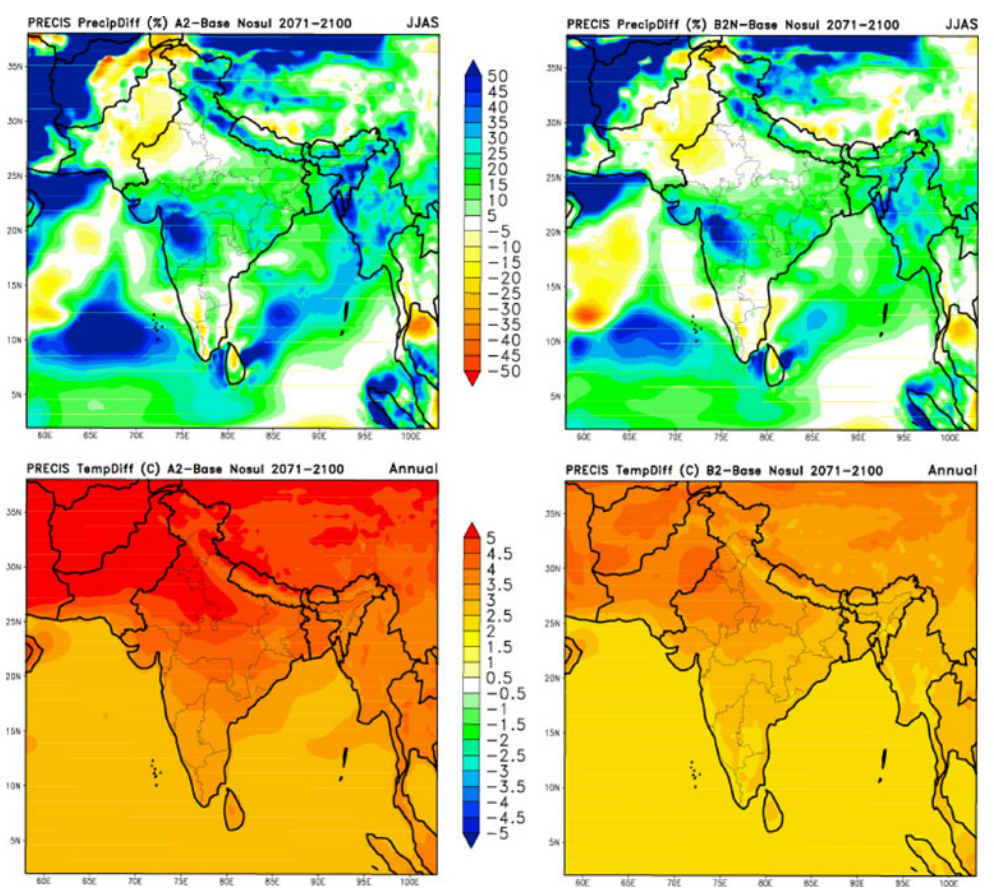

Figure 6: Projections of changes in monsoon precipitation (top) and average annual temperature (bottom) by the end of the twenty-first century for emission scenario SRES-A2 (left) and B2 (right) (Shrestha and Aryal 2011) 


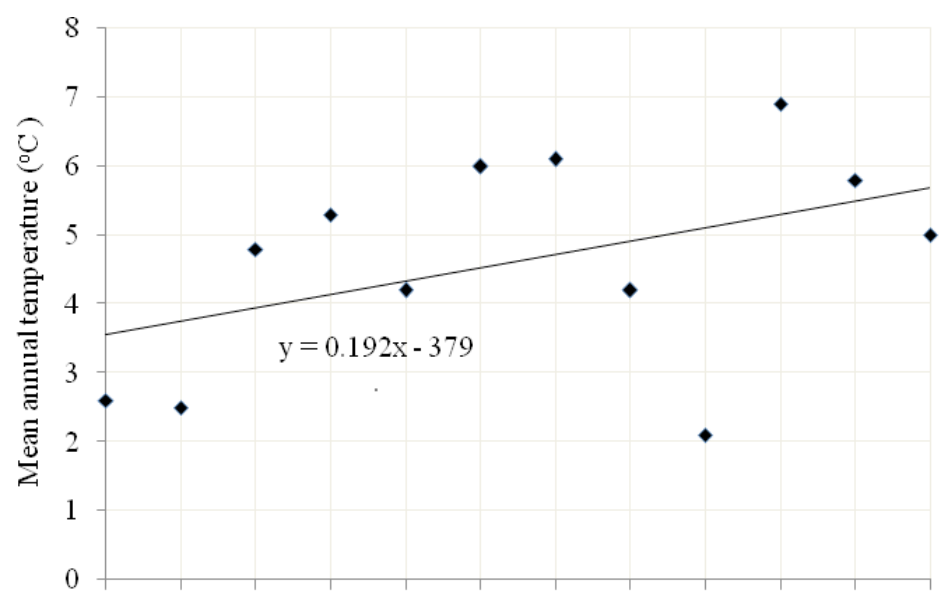

199319941995199619971998199920002001200220032004 Time (y ear)

$0.19^{\circ} \mathrm{C}$ per year from 1993 to 2004 (Aryal et al. 2013).

The rate of warming in Nepal is significantly higher than the global average, which is $0.74^{\circ}$ $\mathrm{C}$ over the last hundred years (ICIMOD 2009).

- Most of the Hindu Kush-Himalayan (HKH) region is situated in the northern part of the Indian sub-continent. The $\mathrm{HKH}$ temperature increase is also outpacing global averages. The central Himalayas (Nepal) and the Tibetan plateau also reflect this sharp warming trend: 0.04 to $0.09^{\circ} \mathrm{C}$ per year and 0.03 to $0.07^{\circ} \mathrm{C}$ per year respectively (ICIMOD 2009). As a result, the number of glacial lakes has increased precipitously, creating additional concern for the potential of GLOF (figure 8).

Figure 8 shows that the Dig Tsho and Imja Figure 7: Average annual temperature at Langtang of Langtang cathchment from 1993-2004 lake areas have been increasing rapidly in size. Tsho

such as early budburst and flowering, new agricultural pests and weeds, and the appearance of mosquitoes. They also reported that temperature increases appeared to be more rapid at higher altitudes.

- Agriculture output. Nepal Agricultural Research Council (NARC) has warned that the effect of a rise in temperature due to global warming will be greater on winter crops like wheat and millet. The vegetative state of those crops would be shorter with higher temperatures, thus lowering productivity (Upreti 2013). All these scenarios are showing that cropping systems could change with climate change.

- Temperature. The average number of 'hot' nights per year in Nepal increased by 9 and the average number of 'cold' days per year has decreased by 19 of days between 1960 and 2003 (UNDP 2008). 'Hot' day or 'hot' night is defined by the temperature exceeded on $10 \%$ of days or nights in current climate of that region and season (UNDP 2008).

- Precipitation. A general circulation model (GCM) projection has shown that mean annual temperatures are projected to increase by 1.3 to $3.80 \mathrm{C}$ by the $2060 \mathrm{~s}$ and 1.8 to $5.80 \mathrm{C}$ by the 2090s (UNDP 2008). Figure 6 illustrates the projection of changes in monsoon precipitation and average annual temperature in Nepal and neighboring countries.

\section{Impact of Climate Change in Glaciers of Nepal Himalayas}

Several temperature analyses in Nepal have
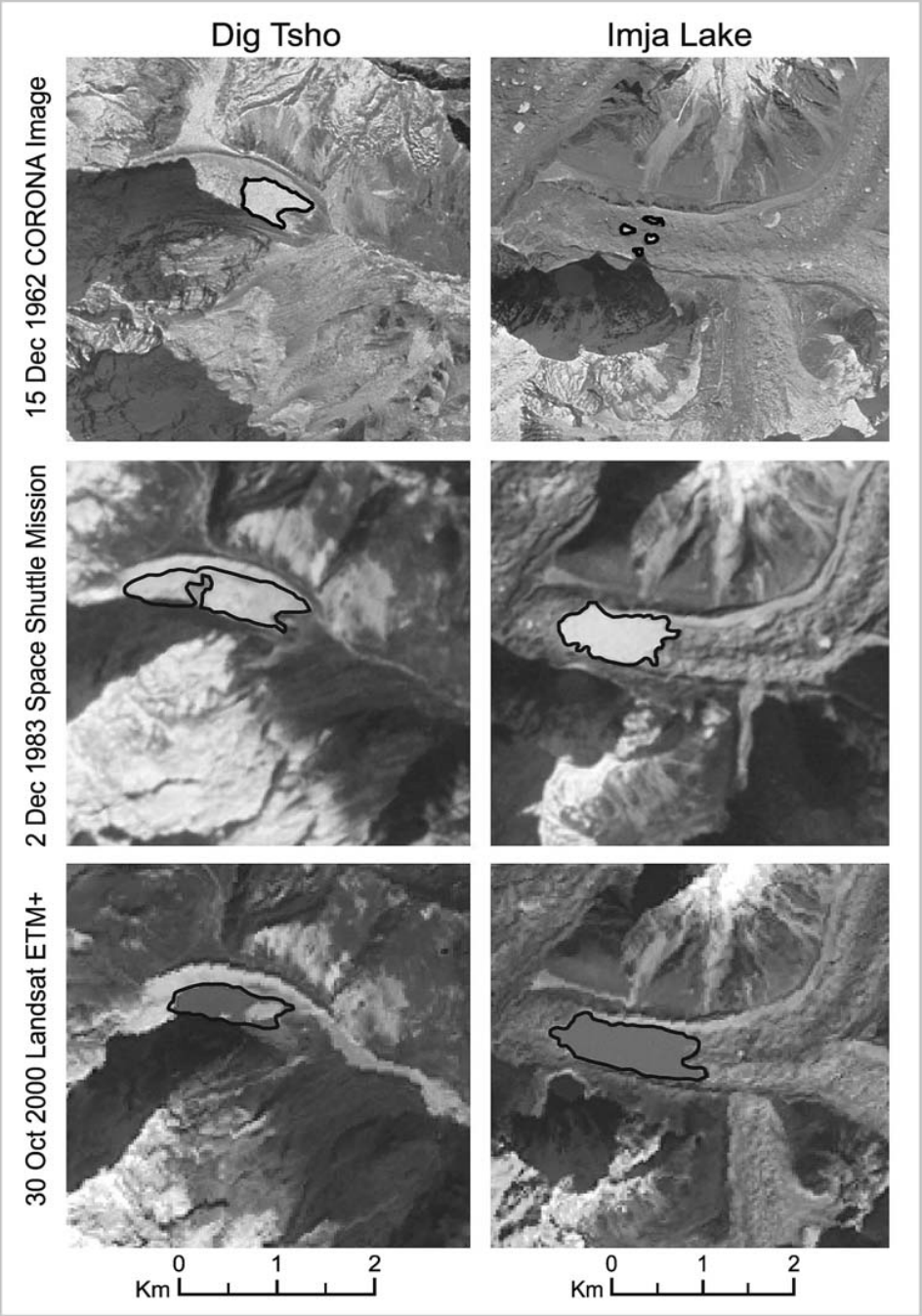

Figure 8: Growth of Dig Tsho and Imja lakes, Nepal (Bajracharya et al., 2007)

Rolpa Glacier Lake can also be considered a vulnerable lake, meaning it has a high likelihood of bursting. The volume of Tsho Rolpa is being reduced by human means to prevent any possible outburst. Tsho Rolpa appeared in 1950 and its size and depth have increased markedly each 


\begin{tabular}{|c|c|c|}
\hline Date & River basin & Name of lake \\
\hline 450 years ago & Seti Khola & Machhapuchhare \\
\hline August, 1935 & Sun Koshi & Taraco, Tibet \\
\hline 21 September, 1964 & Arun & Gelaipco, Tibet \\
\hline 1964 & Sun Koshi & $\begin{array}{c}\text { Zhangzangbo, } \\
\text { Tibet }\end{array}$ \\
\hline 1964 & Trishuli & Longda, Tibet \\
\hline 1968 & Arun & Ayaco, Tibet \\
\hline 1969 & Arun & Ayaco, Tibet \\
\hline 1970 & Arun & Ayaco, Tibet \\
\hline $3^{\text {rd }}$ September, 1977 & Dudh Koshi & Nare, Tibet \\
\hline $23^{\text {rd }}$ June, 1980 & Tamur & $\begin{array}{l}\text { Nagmapokhari, } \\
\text { Nepal }\end{array}$ \\
\hline $11^{\text {th }}$ July, 1981 & Sun Koshi & $\begin{array}{c}\text { Zhangzangbo, } \\
\text { Tibet }\end{array}$ \\
\hline $27^{\text {th }}$ August, 1982 & Arun & Jinco, Tibet \\
\hline $4^{\text {th }}$ August, 1985 & Dudh Koshi & Dig Tsho, Nepal \\
\hline $12^{\text {th }}$ July, 1991 & Tama Koshi & Chubung, Nepal \\
\hline $3^{\text {rd }}$ September, 1998 & Dudh Koshi & SabaiTsho, Nepal \\
\hline
\end{tabular}

Table 2: List of GLOF events recorded in Nepal (WWF 2005)

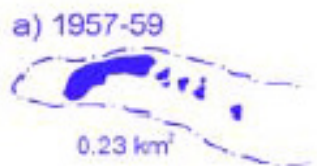

\section{g) $1983-84$}

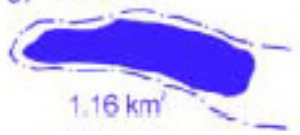

b) $1960-68$

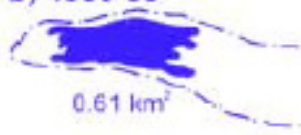

h) $1988-90$

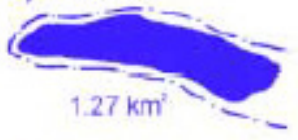

c) 1972

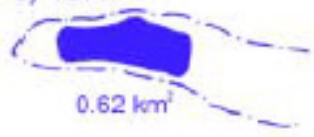

i) 1993

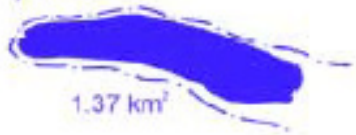

d) 1974

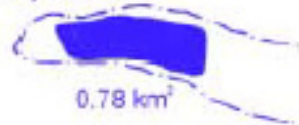

i) 1997

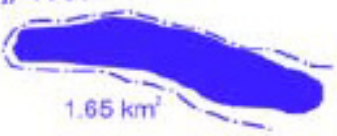

e) $1975-77$

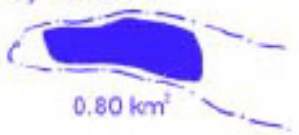

k) 2003

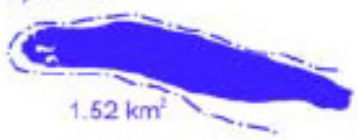

f) 1979

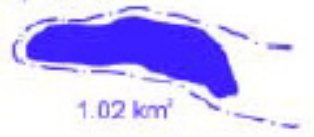

Most hydropower projects in Nepal are built on snow fed rivers like Kali Gandaki, Marsyangdi, and Trishuli. The large amount of glacier melt can impede these projects and dampen their ability to produce electricity, as well as pose serious environmental and humanitarian potentials in the case of dam collapse. It is expected that after glaciers recede to a certain point, river flows will diminish and will not be sufficient to generate electricity. This research at Langtang supports the mentioned claim. Average annual flow obtained at Langtang village in the Langtang catchment and its diagrammatic representation has been given in Figure 10. In a recent study glaciers in the Langtang catchment were observed to be retreating steadily and by 2035 the glacier area will reduce by $32 \%$ (Immerzeel et al. 2012).

Studies have shown that about $20 \%$ of the

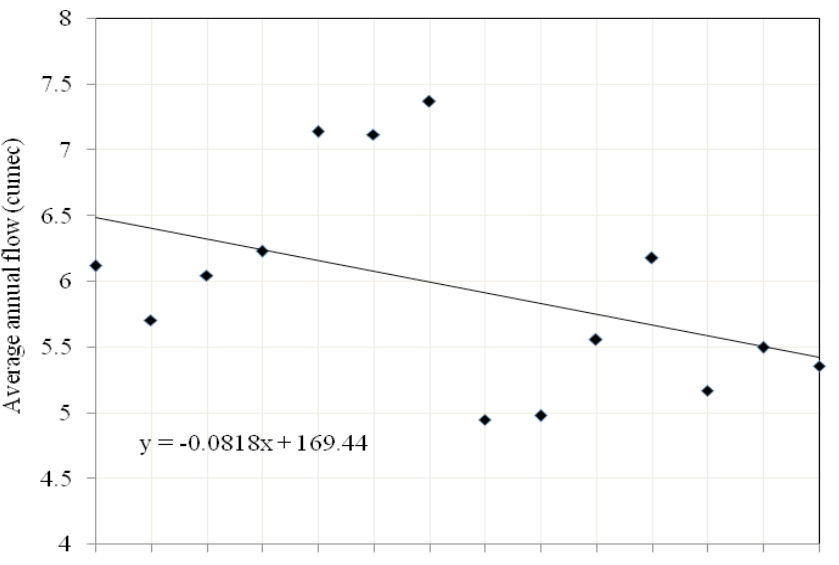

19931994199519961997199819992000200120022003200420052006 Time (y ear)

Figure10: Average annual flow at Langtang village of Langtang cathchment from 1993-2006

glaciated area above 5,00o meters is likely to become snow-and-glacier-free if air temperatures increase by $10 \mathrm{C}$ (NAPA 2008). Around 70\% of the snowcapped area above 5000 meters would be severely affected by an increase of 40C (NAPA 2008). A study from 1988 to 2004 of temperature recorded in the Langtang catchment shows that the total number of days per year below ooC has been decreasing (figure 11).

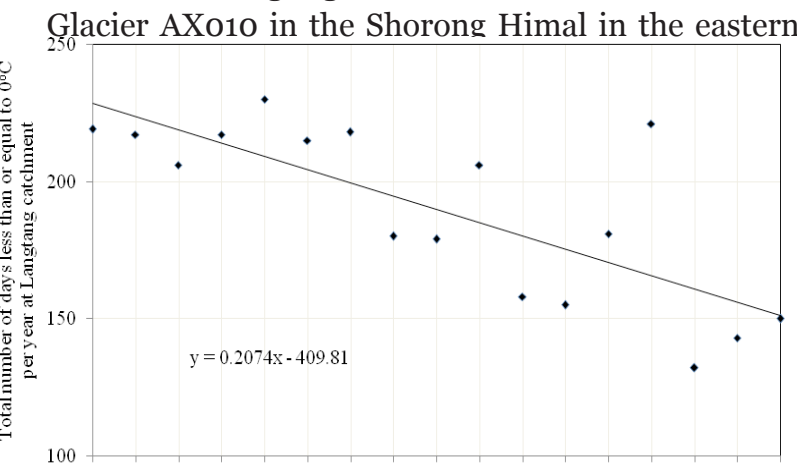

19881989199019911992199319941995199619971998199920002001200220032004 Time (year)

Figure 11: Total number of days less than or equal to $0 \circ \mathrm{C}$ per year at Langtang from 1988-2004
Figure 9: Tsho Rolpa glacier lake area expansion (German watch 2009)

year due to melting glaciers (figure 9). The Trakarding glacier above the Tsho Rolpa Lake is retreating at a rate of 20 meters per year (Shrestha et al. 2011).

A rapid retreating glacier in the Himalayan region is a clear indication of global warming and the climate change. It also shows the growing likelihood of GLOF and events occurred in Nepal (Table 2). 

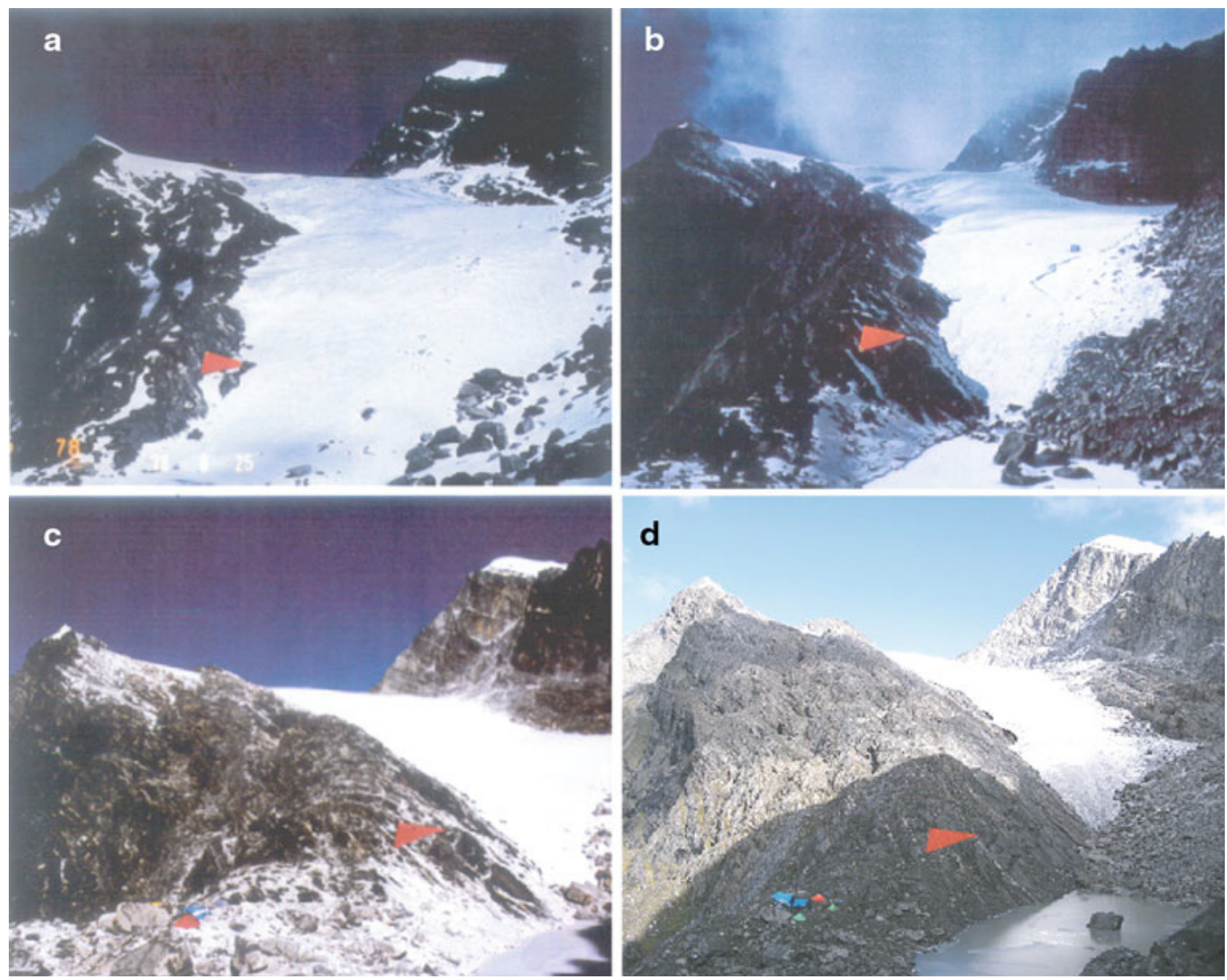

Figure 12: Glacier AX010 in a 1978, b 1989, c 1998 and d 2004 (Shrestha and Aryal 2011)

part of Nepal is one of the most highly studied glaciers.

Figure 12 of the glacier AX010 illustrates the retreating condition of the glacier from 1978 to 2004.

In a recent study conducted on Himalayan glaciers in Nepal and Bhutan, Bajracharya et al. (2011) found that the glaciers are retreating at rates ranging from 10 meters to 60 meters per year and many small glaciers (<0.2 sq. km.) have already disappeared.

Chaulagain (2009) studied glaciers in Langtang Himalayas and found that they may disappear within two centuries at current temperature rates. Seventy-five percent of Langtang glaciers will disappear within 3-4 decades and only $24 \%$ of in the basin may remain by $2100 \mathrm{AD}$ even without any further warming.

\section{Concluding Remarks}

Although Nepal has negligible contribution in global greenhouse gases (GHGs), adverse impacts of climate change are already seen in many parts of the country on water, health, agriculture, forestry, biodiversity and economy. Nepal Himalayas are the main source for the major rivers of the country and most hydro-power projects of Nepal have been constructed on snow fed rivers. Using evidence collected in Langtang, this study indicates that average annual temperature is increasing while annual river flows are decreasing. (It is) also found that the numbers of cold days are decreasing in the catchment. It is worthwhile to mention that further rising temperatures in Himalayan regions of Nepal could exacerbate water scarcity in the nation, which would have serious implications for economic development.

Although the impacts of climate change are found on global scale, Nepal should promote eco-friendly works to reduce the emission of GHGs. Forest conservation, use of renewable energy (including micro-hydro plants), scientific means for realizing urbanization, and waste management are just a few examples of the eco-friendly works that should be enhanced for the good of the nation. Last but not the least, more detailed research on climate change is needed in the Nepal Himalayas to provide policy makers with the best information possible to support effective mitigation and adaptation programs for the country.

Narayan Prasad Gautam, recieve M.Tech. in Hydrology from IIT-Roorkee, India and M.Sc. in Meteorology from Tribhuvan University, Nepal. Presently, he has been working as a lecturer in Department of Meteorology (DOM), Tri-chandra 
multiple campus, Tribhuvan University, Kathmandu, Nepal. since last ten years he has also served as head of the department for couple of years in the DOM. he has carried out many research works in the fields of climate change, discharge analyses, precipitation analyses. he has published multiple numbers of papers and articles in different journals, magazines along with newspapers. Corresponding address: ngautam33@gmail.com

\section{References}

Aryal, A., Brunton, D., Raubenheimer, D., 2013. Impact of climate change on human-wildlife-ecosystem interactions in the Trans-Himalaya region of Nepal. Theor Appl Climatol DOI 10.1007/s00704-0130902-4, Springer-Verlag Wien.

Bajracharya, B., Shrestha, A.B., Rajbhandari, L., 2007. Glacial lake outburst floods in the Sagarmatha region hazard assessment using GIS and hydrodynamic modeling. Mountain Research and Development 27 (4) 336-344. 2007, doi: 10.1659/mrd.0783.1.21

Bajracharya, S.R., Mool, P.K., Shrestha, B.R., 2007. Impact of climate change on Himalayan glaciers and glacial lakes: case studies on GLOF and associated hazards in Nepal and Bhutan. http://books.icimod. org.Accessed 25 December 2011.

Bhutiyani, M.R., Kale, V.S., Pawar, N.J., 2007. Long term trends in maximum, minimum and mean annual air temperatures across the Northwestern Himalaya during the twentieth century. Climatic Change85: 159-177.

Chaudhary, P. and Bawa, K.S., 2011 Local perceptions of climate change validated by scientific evidence in the Himalayas. Biol. Lett. doi:10.1098/rsbl.2011.0269 Published online.

Chaulagain, N.P., 2009. Climate change impacts on water resources of Nepal with reference to the glaciers in the Langtang Himalayas. Journal of Hydrology and Meteorology, 6 (1), Kathmandu, Nepal.

Climate Institute, 2013. Vector-borne diseases. Accessed August 8, 2013

Gaire, N.P., Dhakar, Y.R., Lekhak, H. C., Bhuju, D.R. and Shah, S. K., 2011. Dynamics of Abiesspectabilisin relation to climate change at the tree line ecotone in Langtang National Park. Nepal Journal of Science and Technology, 12, 220-229.

Gautam, N.P., 2005.Climate change and its effect. The Rising Nepal, Gorkhapatra Sansthan, Kathmandu, Nepal.

Gautam, N.P., 2010. Climate change scenario generation using statistical downscaling. M. Tech. dissertation, IIT-Roorkee, Roorkee, India, 1-8.

Gautam, N.P., 200o. Mean annual and flood discharge analyses for Karnali, Narayani, Bagmati and Sapta Koshi River basins. M. Sc. dissertation, Tribhuvan University, Kathmandu, Nepal, 1-10.

German watch, 2009.GLOF in Nepal and Switzerland. http:// www.germanwatch.org. Accessed 10 August 2009.

Grid, 2009. http://www.grid.no/inf/news/newso2/ news309.htm.Accessed 13 August 2009.

Hannah, D.M., Kanskar, S.R., Gerrard, A.J., Rees, G.,
2005. Flow regimes of Himalayan Rivers of Nepal: nature and spatial patterns. Journal of Hydrology308 (1-4): 18-32.

ICIMOD, 2009.Climate change in the Himalayas. International Centre for Integrated Mountain Development, information sheet 3, Kathmandu, Nepal.

ICIMOD, 2002.Inventory of glaciers, glacial lakes and glacial lakes outburst floods, monitoring and early warning system in the Hindu Kush Himalayan Region (Nepal).UNEP.

Immerzeel, W. W., Beek, V.L.P.H., Konz, M., Shrestha, A. B. and Bierkens, M. F. P., 2012. Hydrological response to climate change in a glacierized catchment in the Himalayas. Climatic Change 110:721-736, DOI 10.1007/s10584-011-0143-4.

IPCC, 2008. Climate change and water. Technical paper of the Intergovernmental Panel on Climate Change [Bates BC, Kundzew ZW, Wu S, Palutikof JP(eds.)]. IPCC Secretariat, Geneva, 210pp.

Khalq, M.N. and Cunnane, C., 1997.Climate change and rainfall extreme values: preliminary assessment using a rainfall cluster model. Proceedings of International Symposium, University of Roorkee, Roorkee, India, 1-7.

NAPA, 2008. National adaptation program of action to climate change, Nepal. Ministry of Science and Technology, Kathmandu, Nepal.

Piechota, T.C., Garbrecht, J.D., 2006. Climate variability and climate change, Environmental and Water Resources Institute of the American Society of Civil Engineers, United States of America, 3-18.

Sharma, K.P., III B.M., Vorosmarty, C. J., 2000. Anthropogenic, climatic, and hydrologic trends in the Koshi Basin, Himalaya. Climatic Change47: 141-165.

Shrestha, A.B., Aryal, R., 2011.Climate change in Nepal and its impact on Himalayan glaciers. Reg. Environ Change: S65-S77, DOI 10.1007/s10113-010-0174-9.

Shrestha, B.B., Nakagawa, H., Kawaike, K., Baba, Y., Zhang, H., 2011. Meteorological, hydrological and tsunami disasters: social adaptation and future. The IHP symposium on extreme events, Kyoto, Japan.

UNDP, 2008.Climate change country profile Nepal [Mcsweeney C, New M, Lizano G (eds.)]. School of Geography and Environment, Oxford, United Kingdom.

Upreti, C.R., 2013. Scientist, Nepal Agricultural Research Council, Kathmandu, Nepal (personal communication).

WECS, 2011.Water resources of Nepal in the context of climate change. [Aryal, R.V. \& Rajkarnikar, G. (eds)] Government of Nepal, Water and Energy Commission Secretariat, Singha Durbar, Kathmandu, Nepal.

WMO, 2009.2000-2009 THE WARMEST DECADE. Press Release No. 869, Geneva, Switzerland.

World Bank, 2012. Ganges Strategic Basin Assessment: A Discussion of Regional Opportunities and Risks. World Bank: Washington DC.

WWF, 2005. An overview of glaciers, glacier retreat, and subsequent impacts in Nepal, India and China.WWF Nepal Program, Kathmandu, Nepal. 